\title{
The Impact of Ownership Structure on Innovation Level: Moderating Effect based on the Life Cycle
}

\author{
Yanyun $\mathrm{Nie}^{1,}$, , Huining $\mathrm{Nie}^{2, \mathrm{~b}}$ \\ 1. School of Business, Xi' an International Studies University, Xi' an, China \\ 2. Honors College, Nanjing Normal University, Nanjing, China \\ a3179597871@qq.com, bnhnnnuqhy@163.com
}

\begin{abstract}
Taking listed manufacturing companies in China from 2015 to 2019 as research samples, this paper studies the influence of ownership structure on enterprise innovation level from the perspective of enterprise life cycle by using fixed effect panel regression method. The result shows that when enterprises are at the stage of growing and mature phases, the influence of equity structure on innovation level is similar to that of the whole sample, that is, the increase of ownership concentration and senior executives' shareholding ratio will inhibit enterprise innovation while the increase of ownership balance will promote enterprise innovation. When the firm is in recession, the improvement of ownership concentration and ownership balance will promote the firm's innovation, while the increase of executive ownership will inhibit the firm's innovation. The research enriches the research of influencing factors of innovation, and provide theoretical support for enterprises to improve innovation level by optimizing ownership structure.
\end{abstract}

Keywords: Enterprise Life Cycle; Ownership Structure; Innovation Level; Equity Balance Degree.

\section{Introduction}

Today's society is in the era of knowledge economy, with the rapid development of science and technology and increasingly fierce market competition. Innovation is quite pivotal in economic and social development. Some scholars have pointed out that perfect corporate governance can help enterprises optimize their resource allocation, and then promote enterprise innovation [1-2]. The efficiency of corporate governance is influenced by factors such as ownership structure, management and other stakeholders. Ownership structure, as the foundation of corporate governance structure, is one of the important factors that affect the innovation decision of enterprises, and the relationship between ownership structure and innovation level has also been widely concerned by academic circles.

At present, scholars' research on ownership structure and innovation level mainly focuses on the following aspects. First, through empirical analysis or case analysis, demonstrate the relationship between ownership structure and enterprise innovation level. For example, Guo, Zhu and Zhang use three-stage DEA model to represent ownership structure with the proportion of controlling shares of major shareholders, and conclude that there is an inverted "U" relationship between ownership structure and enterprise innovation[3]; Based on the data of high-tech enterprises from 2010 to 2013, Zhu and Zhou show that the improvement of equity balance will promote enterprise innovation, and there is a significant nonlinear relationship between the proportion of executives' shareholding and the level of enterprise innovation[4]; Taking 73 small and medium-sized listed companies in Yang as research samples, it is found that executive ownership is positively correlated with enterprise innovation, while foreign ownership is negatively correlated with enterprise technological innovation [5]. Secondly, the types of ownership structure are divided into centralized ownership structure and decentralized ownership structure, which explains the differential influence of ownership structure types on their innovation level and verifies the relationship between certain ownership structure and innovation input and output. For example, Gu Lulu and Zhang analyzed the differential influence of centralized ownership structure on enterprise innovation [6]. Zhou takes listed companies in Shanghai and Shenzhen as samples, and proves that decentralization can significantly improve the innovation level of enterprises [7]. Thirdly, enterprises are divided into family-owned enterprises, state-owned enterprises and mixed-ownership enterprises according to ownership. Through empirical analysis or 
case analysis, the relationship between ownership structure and innovation level of certain enterprises is proved. For example, Li Jing's research found that for state-owned enterprises, the improvement of ownership concentration will promote enterprise innovation, while for private enterprises, the opposite is true [8]. Based on the data of A-share family enterprises in China, the empirical analysis method shows that the improvement of ownership concentration in family enterprises will reduce the innovation investment, while equity balance and institutional shareholding can promote the innovation investment [9]. To sum up, the existing literature has conducted in-depth research on ownership structure and innovation level, and due to the different selected samples and research methods, the final conclusions are controversial. In addition, most studies do not consider the influence of the life cycle of enterprises, and ignore the dynamic characteristics of enterprises in each stage of their life cycle. The profitability, cash flow, competitive environment, enterprise scale, and the perfection of corporate governance are all different in four different stages: startup, growth, maturity and decline. The possibility that an enterprise's innovative management decision is influenced by its life cycle cannot be ignored. Therefore, based on the perspective of enterprise life cycle, taking listed companies in China from 2015 to 2019 as research samples, this paper divides the life cycle of enterprises by cash flow combination method, and analyzes the similarities and differences of the impact of ownership structure on innovation level of enterprises in different life cycles. The main contributions are as follows: First, the impact of ownership structure on innovation level of enterprises is explained from the perspective of life cycle, which enriches the research results of influencing factors of innovation level to a certain extent. Secondly, in different stages of the enterprise life cycle, taking improving the innovation level as the starting point, it provides strong empirical support for the company executives to optimize the ownership structure and improve the internal governance, which is conducive to the reasonable and efficient R\&D activities of enterprises.

\section{Theoretical Analysis and Research Assumptions}

There are many empirical variables to measure the ownership structure, such as ownership nature, ownership concentration, ownership balance, senior executives' shareholding ratio and the actual proportion of state holding. From the perspective of stakeholders, this paper chooses three common variables to measure the ownership structure, namely ownership concentration, ownership balance and senior executives' shareholding ratio. These three variables measure different aspects of the ownership structure from the perspectives of controlling shareholders, other shareholders and senior executives, focusing on these three aspects and innovations. Based on the relationship between these three aspects and the level of innovation, this paper puts forward the following hypotheses.

\subsection{The Relationship between Ownership Structure and Innovation Level without Concerning the Enterprise Life Cycle}

First, the impact of ownership concentration on innovation level. According to Du Yingjie's research[10], we can see that many listed companies in China have "one share is dominant", which indicates that the ownership concentration is too high, which may affect the innovation level from the following two aspects: First, based on agency theory, when most of the shares are concentrated in the hands of controlling shareholders, there may be more conflicts of interest between controlling shareholders and other shareholders, and large shareholders may use their control rights to intervene in management's decision-making and seek private control rights. In this case, it is more likely to produce the second kind of agency problem, that is, the major shareholders of the enterprise use the control right to encroach on the interests of the company and occupy the enterprise funds for their own interests, thus making the supply of innovation funds insufficient, reducing the capital investment of the company's innovation activities, and thus reducing the innovation level; Secondly, improving the level of innovation is often inseparable from the independent research and development activities of enterprises. R\&D activities generally have a large investment and a long payback period, which is plagued by market failure, and the $R \& D$ results are highly uncertain. Once R\&D fails, 
compared with minority shareholders, large shareholders with higher shareholding will generally suffer higher losses. Some major shareholders, especially risk-averse shareholders, may choose to reduce their investment in innovation activities to reduce their own risks. At this time, appropriately reducing the concentration of equity may promote the improvement of enterprise innovation level.

Second, the impact of equity balance on innovation level. Equity balance is a phenomenon that the rights of several major shareholders are mutually restrained, which may affect the innovation level from the following two aspects. First of all, equity checks and balances mean that the non-controlling major shareholders' ability to check and balance is improved, which can enable shareholders to supervise each other and restrain each other, form a large control alliance, effectively protect the interests of external investors, increase the difficulty of collusion between controlling shareholders and company executives to prevent collusion between executives and major shareholders, and hinder the controlling major shareholders' behavior of using control rights to seek private interests, and alleviate the problems caused by the phenomenon of "one share dominating the big"[11]. Secondly, the improvement of equity checks and balances strengthens the supervision of other major shareholders on the behavior of company executives to a certain extent, which is conducive to improving the incentive and punishment mechanism for management, thus improving the corporate governance structure, promoting the company's operation to become more scientific and effective, and improving the company's innovation level. Therefore, appropriately increasing the degree of equity checks and balances to increase the right to speak of non-controlling shareholders is conducive to improving the innovation level of enterprises.

Third, the influence of executive shareholding ratio on innovation level. Shareholding executives are both the management and shareholders of the company, and their interests are affected by the salary and bonus linked to performance and the difference between the stock price sold in the secondary market and the authorized price [12]. Based on the moat defense effect, with the increase of executives' shareholding ratio, executives' control over enterprises is increasing, and other binding forces from the outside are getting weaker and weaker, and then executives can use their rights to pursue personal interests in a larger scope. At this time, driven by self-interested motives, executives may ignore the overall long-term interests of the company. Out of defensive psychology, they tend to choose a stable mode of operation, give up technological innovation activities with large investment and long payback period to avoid risks, and then increase stock prices and increase price differences. In this case, an appropriate reduction in the shareholding ratio of executives will promote the innovation level of enterprises.

Based on the above analysis, the hypothesis 1 is put forward that: Without considering the enterprise life cycle, the reduction of ownership concentration and senior executives' shareholding ratio will promote the enterprise innovation level, while the improvement of equity balance will promote the enterprise innovation level.

\subsection{The Relationship between Ownership Structure and Innovation Level after Concerning the Enterprise Life Cycle}

The life cycle of an enterprise refers to the natural time that an enterprise has experienced from its inception to its demise, including four stages: initial stage, growth stage, maturity stage and decline stage [13]. Because the research sample selected in this paper is listed companies, referring to the research of Hou, the initial stage is merged into the growth stage, and the enterprise life cycle is divided into three stages: growth stage, maturity stage and recession stage [14]. At different stages of the enterprise life cycle, enterprises have different characteristics in terms of capital demand, development goals, strategic priorities, profitability, etc. These characteristics may have a certain impact on the relationship between ownership structure and innovation level. The specific analysis is as follows:

The profitability of enterprises in the mature or growth period is relatively strong compared with that of decline period, and the development momentum is good. There are many projects to choose from for investment, and they are faced with numerous challenges and innovation opportunities. At 
this stage, if multiple parties make decisions together, it will help to seek advantages and avoid disadvantages, and get the best innovative scheme. At this time, the reduction of ownership concentration is helpful to multi-party decision-making and enhance the level of innovation; The improvement of equity balance will promote the game between shareholders, avoid the decisionmaking process dominated by a single shareholder or a group of shareholders to a certain extent, and help brainstorm ideas and promote enterprise innovation; Senior executives' appropriate shareholding is an effective way of salary incentive, which solves the agency problem well. However, it should be noted that in the growth and maturity period, the profitability of enterprises is strong. Because the salary and bonus of executives are usually linked to profits, the income that executives can obtain is relatively rich and stable. At this time, executives with a higher holding ratio may not be willing to take the high risks brought by innovation activities for the sake of future high returns, but adopt a conservative management strategy, with the aim of improving the company's short-term profits and ignoring long-term interests. When the shareholding ratio of executives rises to the range of $20 \% \sim 50 \%$, they still face the problem of lack of external supervision, and the behavior of executives to reduce innovation investment in order to maximize short-term benefits may become more serious.

Based on the above analysis, this paper puts forward hypothesis 2: in the growing or mature period, the reduction of ownership concentration and senior executives' shareholding ratio will promote the innovation level of enterprises, while the improvement of equity balance will promote the innovation level of enterprises.

When the enterprise is at the stage of decline, the profit margin is sharply reduced, the market demand is shrinking, and there may be many problems in production and operation [15]. At this time, in the case of high equity concentration, the major shareholders of the enterprise may tend to increase innovation investment to develop the potential of the enterprise in order to reverse the situation. At this time, increasing ownership concentration may promote enterprise innovation; At the same time, due to poor management, employees' morale is relatively low, which will lead to confusion of corporate governance structure to a certain extent. At this time, the improvement of equity balance is conducive to brainstorming among shareholders and improving the decision-making quality of employee appointment or dismissal, thus promoting the improvement of corporate governance structure and improving the company's innovation level; During the recession, the efficiency of personnel control is relatively low. With the increase of the shareholding ratio of executives, the supervisory role of shareholders to managers is weakened, and the pressure on management is obviously reduced. At this time, the increase of the shareholding ratio of executives may have a negative correlation with the innovation level of enterprises.

Based on the above analysis, this paper puts forward Hypothesis 3: For enterprises in recession, the improvement of equity concentration and equity balance will promote the innovation level of enterprises, while the improvement of senior executives' shareholding ratio will inhibit the innovation level of enterprises.

\section{Research and Analysis}

\subsection{Sample Selection and Data Sources}

In this paper, the balanced panel data of China's A-share manufacturing listed companies from 2015 to 2019 are selected, and the following screening and elimination procedures are implemented: 1. Select the enterprises that have been operating continuously during the research period, and eliminate the ST and*ST samples; 2. Eliminate the samples with years or missing indicators; 3. Classify according to the Guidelines for Industry Classification of Listed Companies (2012), and screen out all manufacturing enterprises. Finally, 1436 listed companies were selected, with a total of 7180 sample observations. The data in this paper mainly comes from CSMAR database, and the data processing software is stata15.0. In order to control the influence of extreme value, this paper uses winsor command to shorten the data at $1 \%$ and $99 \%$ percentile. 


\subsection{The Definition of Variables}

\subsubsection{Grouping Variables}

Life cycle. As for the division basis of enterprise life cycle, the research community has not formed a recognized unified standard, and the mainstream division methods mainly include: univariate analysis, comprehensive index method, cash flow combination method, etc. [16]. Referring to Hou's research [16], this paper uses the enterprise cash flow method to divide the life cycle, that is, to judge the different stages of the enterprise life cycle through the direction combination of net cash flow generated by operating activities, investment activities and financing activities in the enterprise cash flow statement. This method emphasizes the direction of cash flow rather than the size of cash flow, so it can effectively reduce the impact of financial data being manipulated artificially. Since all the samples selected in this paper come from listed companies, it can be understood that these enterprises have passed the initial stage, so the life cycle of enterprises is divided into three stages: growth stage, maturity stage and decline stage. The specific judgment criteria are shown in Table 1:

Table 1. Cash flow Portfolio Types in Different Stages of Enterprise Life Cycle

\begin{tabular}{|c|c|c|c|}
\hline Operating Cash Flow & Investment Cash Flow & Financing Cash Flow & Judgment Result of Life Cycle Stage \\
\hline- & - & + & Growth period (initial stage) \\
\hline+ & - & + & growth stage \\
\hline+ & - & - & mature period \\
\hline- & - & - & Decline period (elimination period) \\
\hline+ & + & + & Decline period (elimination period) \\
\hline+ & + & - & Decline period (elimination period) \\
\hline- & + & + & Recession period \\
\hline+ & + & - & Recession period \\
\hline
\end{tabular}

\subsubsection{The Interpreted Variable}

It is not difficult to find that innovation input, innovation output and innovation efficiency are often used to measure the innovation level of enterprises [17-19]. In this paper, innovation input is used to measure enterprise innovation, for two reasons: first, there is a high correlation between the indicators for measuring innovation input and innovation output, and one can be selected; Second, listed companies will disclose relevant information on R\&D investment in financial statements, and relevant data are easy to obtain and accurate. In order to facilitate the analysis and eliminate the influence of excessive regression coefficient, referring to Jia Yong's practice, the total R\&D investment is treated by logarithm.

\subsubsection{Explaining Variables}

Ownership structure: Three indicators are chosen in this paper to measure the ownership structure, namely ownership concentration (TOP), ownership balance (Z) and senior management shareholding ratio $(\mathrm{MO})$.

\subsubsection{Control Variables}

Table 2. Description of variables

\begin{tabular}{|c|c|c|c|}
\hline Type & Name & Symbol & Definition \\
\hline Explained variable & Innovation investment & R\&D & Ln (R \& D investment) \\
\hline \multirow{4}{*}{$\begin{array}{c}\text { Explanatory } \\
\text { variables }\end{array}$} & Equity concentration & TOP & Shareholding ratio of the largest shareholder \\
\cline { 2 - 4 } & Equity balance & $\mathrm{Z}$ & $\begin{array}{c}\text { Shareholding ratio of the second to fifth largest shareholders/ } \\
\text { shareholding ratio of the first largest shareholder }\end{array}$ \\
\cline { 2 - 4 } & $\begin{array}{c}\text { Shareholding ratio of senior } \\
\text { executives }\end{array}$ & MO & Number of shares held by senior management \\
\hline \multirow{4}{*}{$\begin{array}{c}\text { Management cost rate } \\
\text { control variable }\end{array}$} & MR & Overhead/total cost \\
\cline { 2 - 4 } & Turnover rate of total assets & TAT & Total liabilities/ total assets \\
\cline { 2 - 4 } & Management cost rate & FR & Operating income / total assets \\
\hline
\end{tabular}


Referring to Lai Dan's practice, this paper selects four control variables, namely, management fee rate (MR), capital structure (LEV), total asset turnover rate (TAT) and fixed asset ratio (FR) [20]. Specific variable definitions are shown in Table 2.

\subsection{Model and Method}

In order to test the research hypothesis proposed in this paper, the fixed effect panel regression method is used to conduct regression analysis on the whole sample and the sub sample of each stage of the enterprise life cycle:

$$
\begin{aligned}
& R \& D=\alpha_{0}+\alpha_{1} T O P+\alpha_{2} Z+\alpha_{3} M O+\alpha_{4} L E V+\alpha_{5} M R+\alpha_{6} F R+\alpha_{7} T A T \\
& +\sum I n d+\sum Y e a r+\varepsilon
\end{aligned}
$$

\section{Analysis of Empirical Results}

\subsection{Descriptive Statistics}

Table 3 shows the results of descriptive statistics on the model variables, from which we can see: (1) the average ratio of the second to the fifth largest shareholders and the first largest shareholders is 0.75 , the minimum value is only 0.04 , and the maximum value is 2.82 . It can be seen that the overall equity balance is weak, and the phenomenon of "one share dominating" is common in the company. (2) the average shareholding ratio of senior executives is $10.01 \%$, and the maximum is $58.79 \%$, (3) other variables in the model do not have large volatility, which can provide stable data support for the follow-up empirical research.

Table 3. Descriptive Statistical Results of the Whole Sample

\begin{tabular}{|c|c|c|c|c|c|}
\hline Variable & Obs & Mean & Std.Dev & Min & Max \\
\hline R\&D & 7180 & 18.15 & 1.35 & 14.60 & 21.88 \\
\hline TOP & 7180 & 32.71 & 13.56 & 8.88 & 70.22 \\
\hline Z & 7180 & 0.75 & 0.60 & 0.04 & 2.82 \\
\hline MO & 7180 & 0.10 & 0.15 & 0.00 & 0.59 \\
\hline FR & 7180 & 0.23 & 0.13 & 0.02 & 0.62 \\
\hline MR & 7180 & 0.92 & 0.06 & 0.01 & 0.36 \\
\hline LEV & 7180 & 0.39 & 0.18 & 0.06 & 0.84 \\
\hline TAT & 7180 & 0.61 & 0.34 & 0.12 & 2.15 \\
\hline
\end{tabular}

\subsection{Correlation Analysis}

Table 4. Pearson correlation coefficient analysis

\begin{tabular}{|c|c|c|c|c|c|c|c|c|}
\hline & R\&D & TOP & Z & MO & FR & MR & LEV & TAT \\
\hline R\&D & 1.0000 & & & & & & & \\
\hline TOP & $0.0862^{* * *}$ & 1.0000 & & & & & & \\
\hline Z & $-0.0509^{* * *}$ & $-0.5017^{* * *}$ & 1.0000 & & & & & \\
\hline MO & $-0.1964^{* * *}$ & $-0.0741^{* * *}$ & $0.2020^{* * *}$ & 1.0000 & & & & \\
\hline FR & $-0.0085^{* * *}$ & $0.0307^{* * *}$ & $-0.0673^{* * *}$ & $-0.1616^{* * *}$ & 1.0000 & & & \\
\hline MR & $-0.2263^{* * *}$ & $-0.0982^{* * *}$ & $0.0752^{* * *}$ & $0.1744^{* * *}$ & $-0.1380^{* * *}$ & 1.0000 & & \\
\hline LEV & $0.3532^{* * *}$ & $0.0181^{* * *}$ & $-0.0743^{* * *}$ & $-0.2553^{* * *}$ & $0.1306^{* * *}$ & $-0.2272^{* * *}$ & 1.0000 & \\
\hline TAT & $0.2106^{* * *}$ & $0.1075^{* * *}$ & $-0.0998^{* * *}$ & $-0.1438^{* * *}$ & $0.1053^{* * *}$ & $-0.5095^{* * *}$ & $0.1644^{* * *}$ & 1.0000 \\
\hline
\end{tabular}

Note: $* * *, * *$, and $*$ represent significance levels of $1 \%, 5 \%$ and $10 \%$, respectively

Table 4 is Pearson correlation analysis. It can be seen from the table that the correlation coefficient between each variable is not significantly greater than 0.5 , so the possibility of multicollinearity is relatively small. In order to further avoid the problem of multicollinearity among various variables, variance expansion factor test is conducted for the whole sample and the life cycle group sample, it is found that the coefficient of variance expansion among each group of variables is relatively small. 
The largest coefficient of variance expansion is 2.07 , the smallest is 1.05 , and the average value is 1.45 , indicating that there is no serious collinearity problem in the data.

\subsection{Regression Analysis}

Table 5 shows the influence of ownership structure on enterprise innovation level in different stages of enterprise life cycle of model (2) and model (3). The regression results of ownership structure on enterprise innovation level in each stage of enterprise life cycle and in the whole sample are listed in Table 5.

From the regression results of the whole sample, growth period and maturity period, we can see that the ownership concentration and the proportion of senior executives' shareholding are significantly negatively correlated with the innovation level, that is, the increase of the shareholding ratio of the largest shareholder may aggravate the problem of "one share dominating", and then reduce the level of enterprise innovation; there is a significant positive correlation between the degree of equity balance and the level of innovation, which indicates that the checks and balances of other major shareholders are beneficial to avoid the large shareholders occupying the innovation funds, making joint decisions by many parties, and supervising the management's operation behavior, so as to promote enterprise innovation. Thus, hypothesis 1 and hypothesis 2 are verified.

From the regression results of the recession period, it can be seen that the equity concentration and equity balance degree are significantly positively correlated with the innovation level, while the proportion of senior executives' shareholding is significantly negatively correlated with the innovation level, which indicates that in the recession period, the appropriate increase of equity concentration will be conducive to enterprise technological innovation, which may be due to the shrinking profit space of enterprises, considering their own long-term interests, the controlling shareholders increase R \& D investment to win development space for enterprises and promote the improvement of enterprise innovation level.

Table 5. Multivariate Regression Analysis of the Influence of Ownership Structure on Innovation Level of Listed Companies

\begin{tabular}{|c|c|c|c|c|}
\hline Variable name & Full sample & growth stage & mature period & Recession period \\
\hline TOP & $-0.0056^{* * *}$ & $-0.0084^{* * *}$ & $-0.0047^{* * *}$ & $0.0130^{* * *}$ \\
\hline Z & $0.0933^{* * *}$ & $0.1312^{* *}$ & $0.1496^{* * *}$ & $0.3133^{* * *}$ \\
\hline MO & $-1.1357^{* * *}$ & $-1.3627^{* * *}$ & $-1.0160^{* * *}$ & $-1.0153^{* * *}$ \\
\hline FR & $-0.8557^{* * *}$ & $-0.6890^{* * *}$ & $-1.0186^{* * *}$ & $-0.7240^{*}$ \\
\hline MR & $-3.2936^{* * *}$ & $-3.5179^{* * *}$ & $-4.0304^{* * *}$ & $-0.7592^{*}$ \\
\hline LEV & $0.9304^{* * *}$ & $1.3278^{* * *}$ & $0.7930^{* * *}$ & $1.0263^{* * *}$ \\
\hline TAT & $0.2423^{* * *}$ & 0.0350 & $0.1733^{* * *}$ & $0.3223^{* *}$ \\
\hline Cons & $18.3556^{* * *}$ & $18.4275^{* * *}$ & $18.6291^{* * *}$ & $16.6540^{* * *}$ \\
\hline Adj-R 2 & 0.1272 & 0.1142 & 0.1202 & 0.1003 \\
F-Value & $168.05^{* * *}$ & $80.55^{* * *}$ & $147.60^{* * *}$ & $7.74^{* * *}$ \\
\hline
\end{tabular}

Note: $* * *, * *$, and $*$ represent significance levels of $1 \%, 5 \%$ and $10 \%$, respectively

\section{Robustness Test}

In order to test the robustness of the research conclusion, referring to the research by Hou and Liu [16] [21], this paper adds two control variables, namely board size (SOB) and proportion of independent directors (PON), to re regress the model. The results are shown in Table 6.

The regression results of the whole sample and sub samples in each stage in the table are the same as those obtained before, that is, in the growth period and maturity period, the increase of equity concentration and the proportion of senior executives' shareholding will reduce the level of enterprise innovation, and the increase of equity balance will promote enterprise innovation; in the recession period, the improvement of equity concentration and equity balance will promote enterprise innovation, the results show that the increase of executive shareholding ratio will reduce the level of enterprise innovation, and the research results are basically robust. 
Table 6. Test Results of the Relationship between Ownership Structure and Innovation level

\begin{tabular}{|c|c|c|c|c|}
\hline Variable name & Full sample & growth stage & mature period & Recession period \\
\hline TOP & $-0.0058^{* * *}$ & $-0.0085^{* * *}$ & $-0.0054^{*}$ & $0.1264^{* *}$ \\
\hline Z & $0.0862^{* *}$ & $0.1247^{* *}$ & $0.1086^{*}$ & $0.2869^{* * *}$ \\
\hline MO & $-1.1484^{* * *}$ & $-1.3615^{* * *}$ & $-0.6561^{* * *}$ & $-1.0642^{* * *}$ \\
\hline FR & $-0.8394^{* * *}$ & $-0.6839^{* * *}$ & $-1.0334^{* * *}$ & -0.2595 \\
\hline MR & $-3.2939^{* * *}$ & $-3.5298^{* * *}$ & $-4.4313^{* * *}$ & $-0.7627^{*}$ \\
\hline LEV & $0.9273^{* * *}$ & $1.3289^{* * *}$ & -0.1391 & $0.8921^{* * *}$ \\
\hline TAT & $0.2382^{* * *}$ & 0.0295 & $0.1933^{* *}$ & $0.3529^{* *}$ \\
\hline SOB & $0.0254^{* *}$ & 0.0120 & 0.1082 & -0.0020 \\
\hline PON & $0.4057^{*}$ & 0.3603 & 0.5508 & 0.1712 \\
\hline Cons & $17.9750^{* * *}$ & 18.1823 & $18.4759^{* * *}$ & $16.5948^{* * *}$ \\
\hline Adj-R & 0.1398 & 0.1213 & 0.0864 & 0.0910 \\
F-Value & $133.36^{* * *}$ & $62.74^{* * *}$ & $29.33^{* * *}$ & $5.52^{* * *}$ \\
\hline
\end{tabular}

Note: $* * *, * *$, and $*$ represent significance levels of $1 \%, 5 \%$ and $10 \%$, respectively

\section{Conclusion}

From the perspective of enterprise life cycle, this paper uses fixed effect panel regression method to study the relationship between equity structure and innovation level of listed companies from 2015 to 2019, demonstrates the differential impact of ownership structure on innovation level in different stages of enterprise life cycle, and draws the following conclusions: firstly, without considering the enterprise life cycle, the paper analyzes the relationship between equity structure and innovation level of listed companies from 2015 to 2019 , the reduction of ownership concentration will promote the innovation level of enterprises, which may be caused by the problem of " domination of a single share ". The improvement of equity balance will promote the innovation level of enterprises, which may benefit from the collective wisdom of shareholders. Secondly, the growth or maturity of enterprises is similar to the situation without considering the life cycle, that is, the reduction of ownership concentration and the proportion of senior executives' shareholding will promote the improvement of enterprise innovation level, while the improvement of equity balance will promote the improvement of enterprise innovation level; Thirdly, for enterprises in recession, the improvement of equity concentration and equity balance will promote the improvement of enterprise innovation level, which may be due to the fact that enterprises need not only the existence of controlling shareholders to improve innovation efficiency, but also the checks and balances of other shareholders to supervise the behavior of major shareholders. The increase of the proportion of senior executives' shareholding will inhibit the improvement of enterprise innovation level.

Based on the above conclusions, this paper puts forward the following suggestions: firstly, a reasonable ownership structure is conducive to promoting technological innovation of enterprises. Without considering the life cycle of the enterprise, properly improving the degree of equity balance can make the major shareholders restrain each other, reduce the degree of equity concentration and the proportion of senior executives' shareholding to a certain extent can improve the level of innovation; secondly, enterprises in different life cycles should make reasonable adjustments to their own equity arrangement mode. Due to the different impact of ownership structure on innovation level in different life cycle stages, enterprises should judge their own life cycle stage and choose the matching equity structure arrangement to improve the innovation level.

The deficiency of this paper is that the paper only analyzes the impact of equity structure on innovation level in different stages of enterprise life cycle, and does not conduct in-depth study on the differential impact of equity structure on innovation level under different attributes such as property right nature and region. Meanwhile, based on the availability of data, this paper only starts from the perspective of innovation investment, without considering other measurement methods of innovation level, the research results have certain limitations. 


\section{References}

[1] Ma L. Research on Equity Structure Design and Corporate Governance Innovation [J]. Friends of Accounting, 2020 (17): 2-7.

[2] Bloch, F., Hege, U--Multiple Shareholders and Control Contest. Working Paper, HEC School of Management, 2001.

[3] Guo Y., Zhu Y., \& Zhang Y. Research on Ownership Structure and Technological Innovation Level of Listed Companies-based on Three-stage DEA and Tobit Model [J]. Journal of Technology and Economy, 2020, 39(07):128-139.

[4] Zhou X, Zhu D. Ownership Structure, Financial Performance and Cash Dividends [J]. Contemporary Finance and Economics, 2006(05):108-110+115.

[5] Yang D. An Empirical Study on the Influence of Ownership Structure on Technological Innovation of Enterprises-based on the Analysis of Small and Medium-sized Listed Companies in China [J]. Financial Research, 2011(08):56-60.

[6] Gu L., \& Zhang K. Will Centralized Ownership Structure Affect Innovation of Information Technology Enterprises? - Mediating Effect of Non-Executive Directors [J]. Scientific and Technological Progress and Countermeasures, 2021,38(02):75-84.

[7] Zhou X. Decision Power Distribution and Enterprise Innovation [D]. Guangdong University of Foreign Studies, 2020.

[8] Li Jing., \& He X. Ownership Concentration and Innovation Performance: A Comparative Study of Stateowned Enterprises and Family Enterprises [J]. Journal of Business Economics, 2012(10):40-51.

[9] Jane Ling. Ownership Structure and Innovation Investment of Family Enterprises [J]. Accounting Communication, 2020(08):64-68.

[10] Du Yingjie, Liu Yang. Research on Ownership Structure and Related Party Transactions From the Perspective of Enterprise Life Cycle [J]. Accounting Newsletter, 2018(30):85-89+112+129.

[11] Wang J., \& Zhang Y. Ownership Structure, Internal Control Quality and Innovation Investment [J]. Friends of Accounting, 2020(16):109-117.

[12] Pan R. Research on the Influence of Ownership Structure on the Authenticity of Capitalization of R\&D Expenditure [D]. Shanxi University of Finance and Economics, 2019.

[13] Chen X. How to Make a Moderate Investment in Enterprises-based on the Analysis of Enterprise Life Cycle [J]. Friends of Accounting (upper ten-day issue), 2007(07):77-79.

[14] Chang M. Research on Financing Strategy of Small and Medium-sized Technology Enterprises Based on Life Cycle Perspective [J]. Financial Theory and Practice, 2017(10):62-65.

[15] Chen S., \& Chen A. Analysis of Enterprise Life Cycle Division and Measurement Methods [J]. Accounting Monthly, 2012(27):77-78.

[16] Hou Q., Song L., \& Jiang Y. Manager behavior, Enterprise Life Cycle and Inefficient Investment [J]. Accounting Research, 2017(03):61-67+95.

[17] Xie W. Innovation Investment, Ownership Structure and Enterprise Value [J]. Accounting Newsletter, 2017(12):93-97.

[18] Guo Yong. The Impact of Equity Incentives on Enterprise Innovation Efficiency [J]. Friends of Accounting, 2020(12):119-125.

[19] Xiong K. Business Environment, Government Support and Enterprise Innovation Output Efficiency-from the Perspective of Technological Comparative Advantage [J]. Journal of Capital University of Economics and Business, 2020,22(06):83-93.

[20] Lai D., \& Li S. Enterprise Life Cycle, Ownership Structure and Cost Efficiency --Based on the Empirical Evidence of Listed Companies in China's Nonferrous Metals Industry [J]. Friends of Accounting, 2018 (22): 44-50.

[21] Liu Y., Hu K., \& Yu Q. Analysis of Threshold Effect of Financial Deepening on Green Development [J]. China Population Resources and Environment, 2017,27(09):205-211. 